\title{
Examination on Communication and Happiness Levels of Athletes
}

\author{
Serhat ÖZDENK ${ }^{1}$, Kazım KAYA² \\ ${ }^{1}$ Faculty of Sports Sciences in Sinop University, Turkey \\ ${ }^{2}$ Ahi Evran University, High School of Physical Education and Sport, Turkey \\ Address Correspondence to S, Ozdenk, e-mail: sozdenk@hotmail.com
}

\begin{abstract}
Aim: The aim of this study is to investigate the communication skills and happiness levels of athletes engaged in different sports branches. Material and Method: In the research, 240 amateur and professional athletes, who are active in the province of Kırşehir and volunteer, participated in the study. The questionnaire, which was formed in order to determine the characteristics of the athletes, "Communication Skills Assessment Scale (CSAS)" developed by Korkut (19) and Happiness Scale developed by Demirci (9) were used in data collection. Findings: When the happiness levels of the participants were examined according to gender, it was observed that the happiness levels of women were statistically significant compared to men ( $p>0.05$ ), but there was no difference between communication skills according to gender ( $p>0.05)$. It was observed that professional athletes had higher levels of communication skills and happiness than amateur athletes $(\mathrm{p}<0.05)$. In the study, it was seen that the communication and happiness levels of the athletes who have 10 years or more sports experience are higher than the athletes who have less experience $(p<0.05)$. It was seen that the happiness level of the participants who had 3 or more siblings were higher than the participants with 1-2 siblings $(\mathrm{p}<0.05)$. Result: As a result of the research, it was seen that female athletes' happiness levels were higher than those of male athletes, but there was no difference in communication skills of male and female participants. Professional athletes have higher communication skills and happiness levels than amateur athletes and the communication skills and happiness levels of the athletes who have 10 years or more sports experience are higher than those who have less experience. The happiness level of the participants who had 3 or more siblings were higher than the participants with 1-2 siblings.
\end{abstract}

Key words: Sports and communication, sports and happiness, physical activity, sports psychology

\section{INTRODUCTION}

Sport is an important issue in the social sciences because it addresses the goals, objectives and standards that people and societies desire. In general, sport is considered as a means to establish friendships that bring people and countries closer together and sports activities that include not only success criteria such as winning the game or playing well but also the universal values such as fair-play, sportsmanlike conduct, friendship or tolerance, which are related to the quality of the interaction during the activity (4).

As a social being, human beings always have to communicate with the environment regardless of their willingness. The concept of communication is an issue that should be examined in terms of the values to be obtained from the performance of the athlete in the sports field. The use of effective communication skills is an important factor increasing both the performance of the players and the performance of the team (2).
Communication skills can be defined as learned behaviors that facilitate the living of an individual in a society through providing the skills such as effective listening, self-disclosure by means of concrete speech, conveying feelings and thoughts to the other person without hiding out from the others, using verbal and non-verbal messages in a harmonious manner, establishing satisfactory relationships with people based on respect and empathy (18).

Persons involved in sporting activities (athletes, coaches, parents, managers, etc.) can be expected to have an effective communication process. It can be said that communication in sports teams is also important in attaining success and giving the desired performance. In sports, particularly during the coaching process, the relationship between the coach and the athlete plays an important role in the physical and psycho-social development of the athlete (17). 
Physical activity enables people to be happy as it improves and maintains health, which is an important issue for people. Experiments conducted on American and Italian youth have shown that young people tend to be happy as they take part in sports and games (5). Fox (20), demonstrating that participation in physical activity has a positive effect on mental well-being, states that exercise improves mental health by self-perception and is an effective treatment for depression and anxiety. Generally, if exercise increases mental well-being of the individual and reduces the effects of depression and anxiety, it can also affect happiness (16).

Participation in physical activities such as sports or exercise provides opportunities for socializing with people and helps to improve communication skills and happiness so that they can lead an efficient life. It is also generally possible for the person to participate in physical activity to provide long-lasting happiness (16).

The main aim of this study is to evaluate the differences in communication and happiness levels of athletes engaged in sports as amateur and professional according to different variables.

\section{MATERIAL AND METHOD}

Research Model: This research is a descriptive research which addresses the communication skills and happiness levels of amateur and professional athletes actively participating in the sports activities in Kırşehir.

Population and Sample: The population of the study consists of amateur and professional actively participating in the sports activities in Kırşehir. The athletes participating in the study were selected randomly, no criteria were specified for participation in the study and volunteering was taken as the basis.

Data Collection Tools: In the study, Personal Information developed by making a literature review and Communication Skills Assessment Scale (CSAS) developed by Korkut (19) were used as a data collection tool. Communication Skills Assessment Scale is a 5-point Likert-type scale consisting of 25 items and the scale includes the graded options that are " always (5), often (4), sometimes (3), rarely (2), and never (1). The high score stated in the scale, which not includes reverse items, refers to the individuals' positive evaluation regarding their communication skills. The Cronbach's alpha value of the scale was found to be
.86. The Happiness Scale, developed by Demirci, İ. (9), was also used in this study.

\section{INTERPRETATION OF ANALYSIS AND FINDINGS}

Data Analysis: SPSS 19 statistical program will be used for data analysis. The frequency and percentage distributions of the data will be taken, the t-test and the ANOVA test will be used in the parametric groups, and the Kruskal-Wallis and the Mann-Whitney $U$ test will be used in the nonparametric groups.

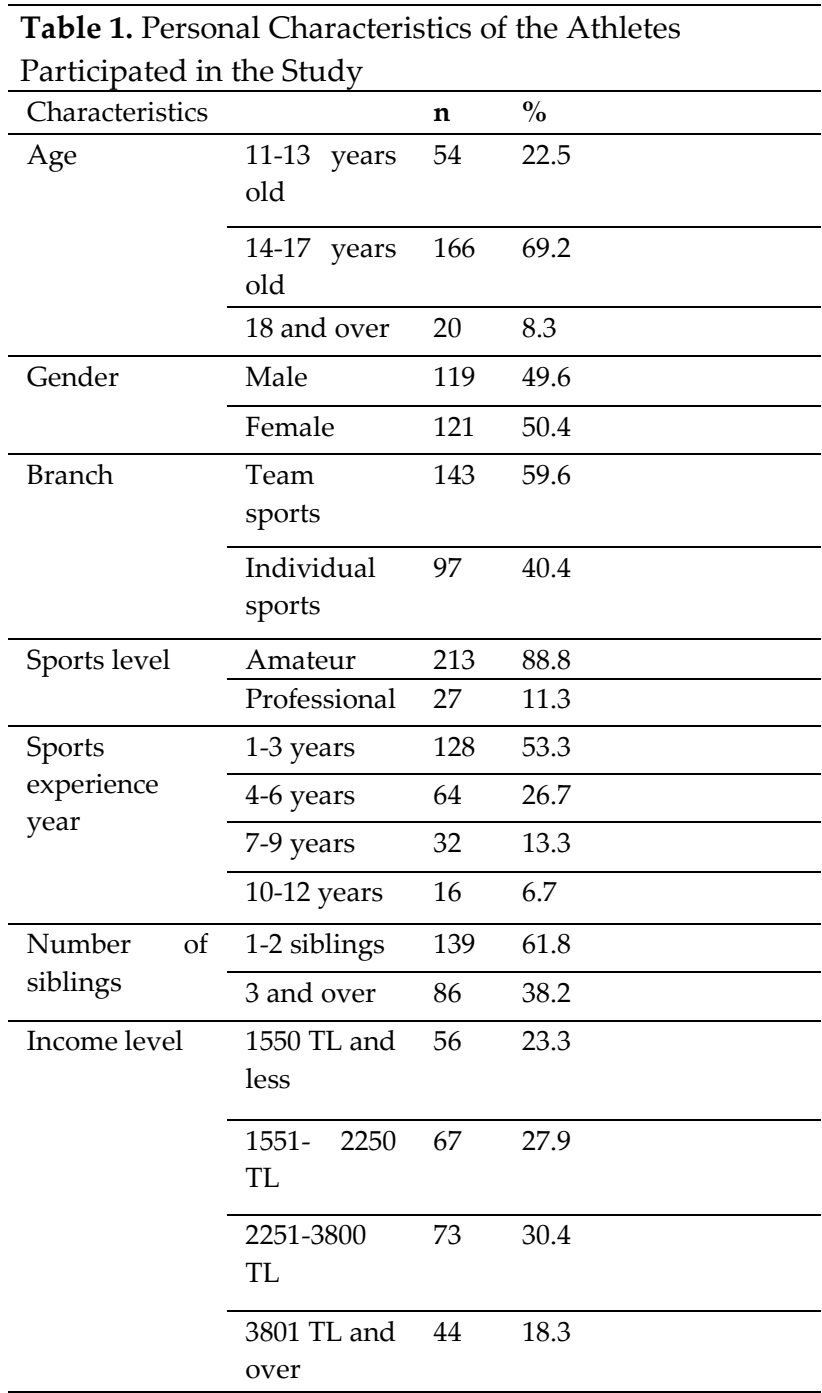

As seen in Table 1, 69.2\% of the athletes participating in the study are $14-17$ years old, $50.4 \%$ of the participants are women, $59.6 \%$ of them are engaged in team sports, $88.8 \%$ of them are amateur athletes, $53.3 \%$ of them have been doing sports for 13 years, $61.8 \%$ of them have $1-2$ siblings, $30.4 \%$ of them have monthly income between the ranges of 2251-3800 TL. 


\begin{tabular}{|c|c|c|c|c|c|c|c|}
\hline Characteristics & & $\mathrm{n}$ & $\mathrm{x}$ & $\mathrm{u}$ & $\mathrm{z}$ & $\mathrm{t}$ & $\mathrm{p}$ \\
\hline \multirow[t]{2}{*}{ Gender } & Male & 119 & 110.55 & \multirow{2}{*}{8.383} & \multirow{2}{*}{2.207} & \multirow[b]{2}{*}{-} & \multirow{2}{*}{0.027} \\
\hline & Female & 121 & 130.28 & & & & \\
\hline \multirow[t]{2}{*}{ Sports level } & Amateur & 213 & 117.29 & \multirow{2}{*}{3.559} & \multirow{2}{*}{2.019} & \multirow[b]{2}{*}{-} & \multirow{2}{*}{0.044} \\
\hline & Professional & 27 & 145.83 & & & & \\
\hline \multirow[t]{3}{*}{ Sports experience year } & $1-3$ years & 128 & 118.65 & & & \multirow{3}{*}{7.257} & \multirow{3}{*}{0.027} \\
\hline & 4-9 years & 96 & 115.52 & & & & \\
\hline & 10 years and over & 16 & 165.19 & & & & \\
\hline \multirow[t]{2}{*}{ Number of siblings } & 1-2 siblings & 139 & 106.26 & \multirow{2}{*}{6.914} & \multirow{2}{*}{1.982} & \multirow{2}{*}{-} & \multirow{2}{*}{0.048} \\
\hline & 3 and over & 86 & 123.90 & & & & \\
\hline
\end{tabular}

As seen in Table 2, when the levels of happiness of the athletes participating in the study were examined by gender, the happiness levels of the female athletes were found to be statistically significant compared to the male ones $(\mathrm{p}<0.05)$.

When the happiness levels of the athletes were examined according to their sports level, it was seen that the professional athletes were happier than the amateur ones $(\mathrm{p}<0.05)$.

When the levels of happiness of the athletes who participated in the study were examined according to their sports level, it was seen that the happiness levels of the athletes who are engaged in sports for 10 years and over were higher than those who are engaged in sports for a shorter period $(\mathrm{p}<0.05)$.

When the happiness levels of the athletes participating in the study were examined according

to their number of siblings, it was observed that the participants with 3 or more siblings had higher levels of happiness than the participants with 1-2 siblings $(\mathrm{p}<0.05)$.

\begin{tabular}{|c|c|c|c|c|c|c|c|}
\hline Characteristics & & $\mathbf{n}$ & $\mathbf{x}$ & $\mathbf{u}$ & $\mathrm{z}$ & $t$ & p \\
\hline \multirow[t]{2}{*}{ Gender } & Male & 119 & 114.5 & \multirow{2}{*}{7.913} & \multirow{2}{*}{1.328} & \multirow{2}{*}{ - } & \multirow{2}{*}{0.184} \\
\hline & Female & 121 & 126.4 & & & & \\
\hline \multirow[t]{2}{*}{ Sports level } & Amateur & 213 & 116.32 & \multirow{2}{*}{3.765} & \multirow{2}{*}{2.618} & \multirow{2}{*}{-} & \multirow{2}{*}{0.009} \\
\hline & Professional & 27 & 153.44 & & & & \\
\hline \multirow[t]{3}{*}{ Sports experience year } & $1-3$ years & 128 & 112.75 & & & \multirow{3}{*}{15.636} & \multirow{3}{*}{0.001} \\
\hline & $4-9$ years & 96 & 120.01 & & & & \\
\hline & 10 years and over & 16 & 185.50 & & & & \\
\hline \multirow[t]{2}{*}{ Number of siblings } & 1-2 siblings & 139 & 106.47 & \multirow[b]{2}{*}{6.884} & \multirow{2}{*}{1.912} & \multirow[b]{2}{*}{ - } & \multirow[b]{2}{*}{0.056} \\
\hline & 3 and over & 86 & 123.55 & & & & \\
\hline
\end{tabular}

As seen in Table 3, when the level of communication skills of the athletes participating in the study is examined by gender, it is observed that the level of communication skills of the female athletes is not statistically significant compared to the male athletes $(\mathrm{p}>0.05)$.

When the communication skills of the athletes were examined according to their sports level, it was seen that the level of communication skills of the professional athletes was higher than the amateur athletes $(\mathrm{p}<0.05)$.

When the communication skills of the athletes who participated in the study were examined according to the sports experience years, it was seen that the communication skills levels of the athletes engaged in sports for 10 years or more were higher than those who are engaged in sports for a shorter period $(\mathrm{p}<0.05)$.

When the level of communication skills of the athletes participating in the study was examined according to the number of siblings, it was determined that the result was not statistically significant $(\mathrm{p}>0.05)$.

\section{CONCLUSION AND EVALUATION}

In this study, communication skills and happiness levels of athletes engaged in sports as amateur and professional were examined according to different variables. 
As a result of the study, when the happiness levels of the athletes participating in the study were examined by gender, the happiness levels of the female athletes were found to be statistically significant compared to the male athletes $(\mathrm{p}<0.05)$.

Tingaz and Hazar (23) stated in their study that according to the gender of the students studying in the Physical Education and Sports Teaching Department, the mean of happiness levels of the female students $(115.46 \pm 17.2)$ is higher than that of male students $(113.18 \pm 17.2)$.

In their study, Gülcan et al. (12) and Gökdemir and Dumludag (10) found that the mean of happiness level scores of female participants were significantly higher than that of the male participants.

According to the gender, there were no statistically significant differences in the communication skills level of the athletes participating in the study $(\mathrm{p}>0.05)$.

In the studies conducted by Mutlu et al. (20) and Çavuşoğlu and Günay (7), it was observed that the mean of communication level of the athlete students did not constitute a statistically significant difference according to the gender variable and in the studies conducted by Dalkılıç (8) and Çiçek (6), it was seen that there was no significant difference between the communication skills of male and female athletes in terms of the gender variable.

In a study conducted by Hacicaferoğlu et al. (14) regarding the examination of the views of student-athletes playing in the intervarsity minor volleyball league in Turkey on their communication and performance efficiency, it was asserted that there are no differences in terms of the gender variable.

In the study conducted by Gün (13), in which communication skills of prospective music teachers were examined, it was found that there was no significant difference between the communication skills scores of the prospective music teachers and the gender variable.

When the happiness and communication skill levels of the athletes who participated in the study were examined according to their sports levels, it was observed that the professional athletes had higher levels of happiness and communication skills compared to the amateur athletes $(\mathrm{p}<0.05)$.
It was found in several studies that sportive participation significantly improves and influences communication skills (8). Hacıoğlu (15) concluded in the study conducted on "Examining the Body Image Satisfaction and Communication Skills of University Students" that the body satisfaction and communication skills of the students engaged in sports at a professional level were higher than the ones at an amateur level.

In a study, which reveals the communication level differences of professional and amateur football players with the coach, Abakay and Kuru (1) determined that communication level of professional football players with the coach is higher than that of amateur football players.

In a study conducted by Şahin (22), it was determined that the communication skill scores of the volleyball players in the successful group were high (95.44). Şahin stated that the high level of communication skills of professional athletes is caused by professional athletes have to communicate with many people, different lifestyles and daily habits (22).

According to the happiness and communication levels by sports experience year, it was observed in the study that the communication and happiness levels of the athletes who have 10 years or more sports experience are higher than the athletes who have less experience.

In the study carried out on Perceptions of Professional Basketball and Volleyball Players on Communication Skill Levels with the Coach and Anxiety Levels of Athletes, Ateş et al. (3) determined that the athletes who have 22 years and over sports experience perceive their coach's communication skills at a higher level than those who have 7 years or less sports experience.

As a result, it was stated that coping strategies of the athletes regarding training and competition conditions, referees, teammates, interacting with the other athletes and the other concrete and abstract factors will be improved as sports experience period increases, thus, this situation may increase the communication skills of athletes (3).

The high level of communication skills and happiness levels of the individuals engaged in sports can be caused by the fact that the athletes are in contact with many different individual/s due to the excess and variety of communication fields (team-mate, coach, spectator) within the active 
sports lives. Considering some psychological positive effects of sports, it is thought that the level of communication and happiness may be increased as the sports experience period increases.

Age and experience, as in any professional group, is quite important for athletes. People learn the most accurate information by experience throughout their lives. Our knowledge and experience are always the vital factor in learning better and more accurate things. Similar results were not found in the literature on the age of athletes, however, some studies that determine the happiness and communication skills of the athletes according to the age variable are in parallel with the results that we have found.

In the study, which is titled as Comparison of Emotional Intelligence and Happiness of Prospective Physical Education and Sports Teachers and Some Other Prospective Teachers, it was stated that the mean values of happiness of students in the $22+$ age group $(117.43 \pm 18.03)$ were higher than those of the 18-22 age group $(113.05 \pm 17.28)$ (24).

Razi et al. (22) also found that there was a significant difference between the age group of 20-24 and the age group of 15-19 in terms of communication skills. The mean of communication skills of 20-24 age group was higher than that of the 15-19 age group.

In the study conducted by Görür (11) with adolescents, it was shown that the findings about the perception of communication skills have a significant difference in favor of the adolescents who were relatively older.

As a conclusion, it can be said that the level of communication and happiness of the athletes increases, as the sports level (amateur, professional) and sports experience year increase, and that the athletes can adapt themselves more easily to their social environment and therefore they can be happier and more successful in the social life.

\section{Acknowledgements}

This study was presented as oral presentation at the 6th International Conference on Science Culture and Sport 2018. Also thanks to Gülcan Demir Özdenk, Dede Baştürk and Ziya BAHADIR for help in the study.

\section{REFERENCES}

1. Abakay U, Kuru E. Profesyonel ve Amatör Futbolcuların Antrenörleri ile Olan İletişim Düzeyi Farklılıklarının Karşılaştırılması. Selçuk Üniversitesi Beden Eğitimi ve Spor Bilimleri Dergisi, 2011; 13(1) : 125-131.

2. Abakay U, Kuru E. Kadın futbolcularda antrenörle iletişim düzeyi ve başarı motivasyonu ilişkisi. Gaziantep University, Journal of Social Sciences, 2013; 12(1): 20-33.

3. Ateş C, Yıldız Y, Yıldız K. Profesyonel Basketbol ve Voleybolcuların Antrenör İletişim Beceri Düzeyleri Algısı ve Sporcuların Kaygı Düzeylerinin Araştırılması. Erciyes Üniversitesi İletişim Fakültesi Akademik Dergisi, 2018; 5(3), 40-52.

4. Başaran Eİ. Eğitim psikolojisi eğitimin psikolojik temelleri. Gül Yayınevi, Ankara, 1998: 112- 113. Csikszentmihalyi M, Wong $M$. The situational and personal correlates of happiness: A cross-national comparison N.S. Michael Argyle (Ed.), Fritz strack, Subjective well-being: An interdisciplinary perspective, Pergamon Press, Oxford, 1991; 193-212

5. Çiçek G. Spor Yapan ve Yapmayan Yetişkin Bireylerin İletişim Becerileri Düzeylerinin Karşılaştırılması. Electronic Turkish Studies, 2018; 13(19)

6. Çavuşoğlu SB. Günay G, İstanbul Üniversitesi Beden Eğitimi ve Spor Yüksekokulu Öğrencilerinin İletişim Becerileri Alg1 Düzeylerinin Farklı Değişkenler Açısından Değerlendirilmesi. Organizasyon ve Yönetim Bilimleri Dergisi, 2014; 6(1): 107-121

7. Dalkılıç M. İlköğretim Öğrencilerinin Sportif Faaliyetlere Katılım Düzeyi ve İletişim Becerileri Düzeyi Arasındaki İlişkilerin İncelenmesi. Karamanoğlu Mehmet Bey Üniversitesi. Sosyal Bilimler Enstitüsü, Yüksek Lisans Tezi, Karaman, 2011.

8. Demirci İ. Huzurlu ve mutlu yaşamın değerler ve karakter güçleri bağlamında karma bir araştırmayla incelenmesi (Doktora tezi, Marmara Üniversitesi, Eğitim Bilimleri Enstitüsü, İstanbul), 2017.

9. Gökdemir-Dumludağ Ö. Mutluluk ve iktisadi parametreler üzerine bir inceleme (Doktora Tezi). İstanbul Üniversitesi Sosyal Bilimler Enstitüsü, İstanbul, 2011.

10. Görür D. Lise Öğrencilerinin iletişim Becerilerini Değerlendirmelerinin Bazı Değişkenler Açısından, İncelenmesi. Çukurova Üniversitesi Sosyal Bilimler Enstitüsü, (Yayımlanmamış Yüksek Lisans Tezi), Adana, (2001).

11. Gülcan A, Nedim-Bal P. Genç yetişkinlerde iyimserliğin mutluluk ve yaşam doyumu üzerindeki etkisinin incelenmesi. Asya Öğretim Dergisi, 2014; 2(1), 41-52.

12. Gün, E. Müzik Öğretmeni Adaylarının İletişim Becerileri. Electronic Turkish Studies, 2018;13(11).

13. Hacicaferoğlu S, Korkmaz M, Atalay A, Yücel AS. Köksal H. Türkiye'de üniversiteler voleybol 2.liginde oynayan öğrencisporcuların iletişim ve performans verimine yönelik görüşlerinin incelenmesi. Uluslararası Hakemli Akademik Spor Sağlık ve Tıp Bilimleri Dergisi,2015; 5(16); 88- 107.

14. Hacıoğlu M. Üniversite Öğrencilerinin Beden İmgesi Hoşnutluğu ve İletişim Becerilerinin İncelenmesi. Gaziantep Üniversitesi, Spor Bilimleri Dergisi. 2017; 2(2),s: 1-16

15. Huang H, Humphreys B. Sports participation and happiness: evidence from US microdata. Journal of Economic Psychology 2012; 33( 4): 776- 793. 
16. Jowett S, Cockerill I. Incompatibility in the Coach-Athlete Relationship. In: Cockerill I, Ed. Solutions in Sport Psychology. London: Thompson Learning, 2012.

17. Kaya A. Kişilerarası İlişkiler ve Etkili İletişim. Ankara: Pegem Akademi, 2012.

18. Korkut F. “İletişim Becerilerini Değerlendirme Ölçeğinin Geliştirilmesi: Güvenirlik ve Geçerlik Çalışmaları", Psikolojik Danışma ve Rehberlik Dergisi, 1996; Cilt: 2, Sayı: 7, ss. 18-23.

19. K. Fox The influence of physical activity on mental wellbeing Public Health Nutrition, 2, 1999; 411-418

20. Mutlu OT, Şentürk HE, Zorba E. Üniversite Öğrencisi Tenisçilerde Empatik Eğilim ve İletişim Becerisi, International Journal of Science Culture and Sport, 2014;129-37.

21. Razı GS, Kuzu A, Yıldız AN, Ocakçı AF, Çamkuşu Arifoğlu B. Çalışan gençlerde benlik saygısı, iletişim becerileri ve stresle baş etme. TAF Preventi ve Medicine Bulletin.; 2009; 8(1):17-26.

22. Şahin N. Elit düzeyde takım sporu ve bireysel spor yapan iki grubun iletişim becerilerinin karşılaştırılması, Spormetre Beden Eğitimi ve Spor Bilimleri Dergisi, 2012; (1) 13-16.

23. Tingaz EO, Hazar M. Beden eğitimi ve spor öğretmenliği ile bazı öğretmen adaylarının duygusal zekâ ve mutluluklarının karşılaştırılması. International Journal of Science Culture and Sport, 2014; 1: 745-756 